\title{
COVID-19 Narratives in a Carpatho-Rusyn Village in Transcarpathian Ukraine
}

\author{
Elena Boudovskaia \\ Georgetown University \\ Washington DC, USA
}

\begin{abstract}
In a Carpathian village whose tradition I have been studying for a number of years, in pre-COVID-19 narratives about illness, an unexpected illnessespecially a potentially fatal one - was often viewed as a sign from above. Depending on the relation between the speaker and the affected person, it might either cast doubt on the person's behavior or indicate an undeserved tragic stroke of fate. This paper examines whether that has changed during the COVID-19 pandemic. I explore how people in this village talk about the pandemic, and how their narratives fit into, and possibly add to, our understanding of traditional values, supernatural beliefs, and the linguistic expression of these values and beliefs in the village.
\end{abstract}

Introduction

In March 2020, at the beginning of the COVID-19 pandemic, I frequently talked on the phone with my friends and acquaintances in the village of Novoselytsia, (1) where I have conducted research for a number of years. I was concerned about their safety and well-being, as they were about mine. During our conversations, I could not help but notice that the stories they told me appeared to be closely related to the narratives I had heard during our interviews in previous years on the topics of health, disease, and cultural values. I then conducted a number of phone interviews in Novoselytsia that shed new light on how the speakers' understanding of disease fed into the perception of one's place in the world in Novoselytsia's culture. For this article, I have summarized ten interviews conducted between March and December 2020.

In this article, I classify and analyze COVID-19 related stories told during interviews as well as their functions in conversation. Since the speakers do not want to be identified, I can only say that they are locally born women, all between the ages of 40 and 65 . The narratives, including stories about disease, death, and recovery, usually do not have supernatural elements and are not connected with ritual, so some might argue that they should not be considered folklore. However, since they have patterns that repeat from person to person, are widely used, and apparently reflect a traditional worldview, I consider them to be not only speech genres, but also folklore genres. 
Narrative in the Culture of Novoselytsia

Narrative is the chief manner in which my interviewees perceive and think about the world. Asked directly what they think about a certain issue, they will answer with a story. In their spontaneous speech, one story flows into another. These stories are not always chunks of text remembered and repeated, although in some cases they might be. A story about death, for example, is constructed again for each death and is repeated thereafter, being re-composed each time extemporaneously, but also becoming more and more committed to memory with each repetition. Like memorates, a death story describes an event that happened once in the speaker's surroundings. As the story is told again and again, it is shaped by the expectations and feedback of listeners and by the shared culture of the participants. Thus, a death story also functions like a memorate, serving as a window into the traditional worldview of the culture. Similarly, recent COVID19 stories have been constructed along culture-specific lines and told in accordance with the speaker's expectations. Although not enough time has elapsed for these narratives to solidify into stories transmitted from memory, COVID-19 stories, nevertheless, reveal cultural patterns. The question I address here is if these patterns have been changed by the unprecedented pandemic and if new patterns have emerged.

I examine several types of stories told in connection with COVID-19, analyzing their features and usage. First, I discuss narratives about people known to the narrators: stories of disease, death, and recovery. I also touch upon stories of COVID-19 transmission in the community. Then I briefly analyze stories of political events, which is a much larger topic needing more analysis; however, I outline a number of important points in my examination of political stories as a narrative genre of village discourse connected to, and contrasted with, personal and vicarious experience stories. In addition, I examine linguistic patterns of talking about the supernatural to investigate culturally defined ways to control fate. Finally, I summarize my findings about narrative patterns in COVID-19 stories.

Stories about People's Death and Disease: Structure, Features, and Usage

Many COVID-19 stories follow established story types and are structured accordingly. In my previous research, I have examined death stories in Novoselytsia as a window into the community's ideas, values, and identity construction in several crucial areas. In the course of my work on this topic, I have identified three main types of death stories: 1) "good death of a good person" or "death of a relative;" 2) "bad death of a good person" or "death of a neighbor;" and 3) "bad death of a bad person" or "death of a witch." 
In the first type of story, the deceased is described as a good person and her/his death should be considered a "deservedly good" death. The components of a good death include: 1) one is conscious and aware of one's dying; 2 ) one is not suffering; 3) dying happens over a short period of time, but not instantaneously, e.g., from an accident; 4) after death the deceased looks almost the same as in life. (2) It is also a good thing for a person to die at home, not in a hospital, and to have her/his family present. The death that includes all these elements promotes envy in others and might be granted to a person who has lived a good life. One can pray for such death in order to receive it. A good person goes to the afterlife almost without changes, as $\mathrm{s} / \mathrm{he}$ was in life. From beyond the grave, these people can communicate to their families in dreams, passing along the message that they are well, or even helping out their families by instructing them about the proper course of action to take regarding certain matters or by revealing the future.

The second type, "bad death of a good person," includes stories about fatal accidents, murders, and even some suicides, where the deceased was perceived as innocent, but the unfortunate death requires explanation. These stories are most often told about neighbors whom the speaker perceives as being generally good or about such deaths in the narrator's family. Some common structural features of such stories include: 1) praise for the character and achievements of the deceased; 2) counterfactual constructions in the subjunctive mood: "if it were not for ..., s/he would have lived longer." This subjunctive construction invokes a hypothetical normal world order, highlighting that the deceased could have lived longer had something not interfered with the norm. Overall, regarding tone and structure, these narratives resemble abbreviated funeral laments. Often the untimely death is explained as having been predestined, but not deserved, or else is not explained at all. If the deceased characters from these stories appear in dreams, they ask that various objects or services be provided to poor neighbors. These charitable acts are believed to ultimately reach the deceased who made the request.

The third type, "bad death of a bad person" or "death of a witch," is told by people unrelated to the deceased, especially by those who have something bad to say about her/him. Such deaths are described by my interlocutors as a retribution for "great sins," especially witchcraft. The elements of such stories are the opposite of what we can see in the "good death of a good person" stories: 1) the death is described as prolonged and painful; 2) after death, the body might be distorted and ugly, showing signs of early decomposition. (3)

The COVID-19 death stories I heard in 2020 and early 2021 were constructed along similar lines and have the same structural elements as these death and illness stories do. The main difference is that none of the stories contain any supernatural components, such as communicating with relatives from beyond the grave. This fact may be due to my interlocutors being members of a younger generation, with relatively high educations (at least some high school), who construct themselves as not superstitious. It may also be that the stories were not 
yet fully developed; they were generally short and bore other markers of nascence. Supernatural elements may be introduced later, when more time has passed after the actual deaths. (4) Another important difference is that practically all COVID19 death stories reported by my interlocutors fall into the second category: "tragic/bad death of a good person." Even if the speakers strongly disapproved of the deceased's actions (e.g., when talking about a woman who came home sick from Italy, and, before becoming bedridden, visited many in their homes and attended a church service, spreading COVID-19 all over her village), the speaker did not add any features of the "bad death" story to the narrative. On the contrary, practically all COVID-19 death stories contain praise for the deceased and convey the distinct feeling that the death should not have occurred. That was the case both when a speaker talked about deaths of people whom she knew, at least by hearsay, as well as about deaths she learned of from mass media. Below are two excerpts from conversations, one about the deaths of two people the speaker knew, and the other about the deaths of two people unknown to her:

1) В: ... таі лікарі́ | у [...] в [...] два́ чи три́ лікарі́ уме́рли | на коิві́д сього́дні | сякі́ то спра́вы |

Author: Кі́льки уме́рло?

В: Маіже три́ | два́ або три́ лікарі́ |

Author: Бо́же

В: Но | тай такі́ шче | бо у фе̂йсбу́коิви ба́чила такі́ фа́йні чоิлоิвікб́ пі́т шизьдіся́т ро̂́ків шче̂ й не было шізьдіся́т тай

Author: Бо́же

В: Тай шчо́ зроби́ти тай чи ви́дите біда́ тоिї біды́ є до́ста тай гото́во |

[B: ... And doctors ... In [another district center in the region], where MM lives, two or three doctors died of COVID, today, that is how it is.

Author: How many died?

B: Maybe three, two or three doctors

Author: My God!

B: Yes. And they were also...I saw it on FB: such nice men, less than 60 years old, younger than 60 .

Author: Oh my God!

B: But what's to be done? Do you see, it is a misfortune $[$ bida] (5), there is a lot of this misfortune, and that's how it is] [Informant B, 22

December 2020]

2) Мно́го хво́рых та́й | а лю́ди то́ не | не хо̂́тят признава́ти $\mid$ у ... $\mid$ позавчо́ра м чита́ла $\mid$ у чоิрнівця́x $\mid$ i $\mid$ ре́ктор поме́р від коิвіду $\mid$ i $\mid$ дека́н | тай такі́ шче фа́йні такі́ бо нее́ | шчобы ду́же старі́ | то́т єде́н мо́же де̂́зь до́ пядеิся́т ро̂́ків а дру́гый | но піт шеิзьдьеิся́т такі́ фа́йні люди | у льво̂́ві та̣ко́ш | яки́йсь выклада́ч | політехни́чного інститу́ту | на ковід помер | $\mid$ тоि́і біды́ а ліка́рства ви́дите нема́ тай шчо́ роби́ти | 
[There are a lot of sick people, and that's it, and people don't want to acknowledge it ... I yester ... I read the day before yesterday, in a paper, that in Chernivtsi, a dean and a president [of a university] both died of COVID. And they were both such healthy people, and not old, that one was less than 50, the other, near 60, such good people. In Lviv, too, a professor of a Polytechnic University died of COVID. There is a lot of that misfortune [bidY], and there is no cure, so what's to be done?] [Informant A, 1 November 2020].

The first speaker praises the dead doctors: they were professional, educated city-dwellers, i.e., belonged to the class that peasants call pany [gentlemen] and consider to be above the peasant class. She also calls them "nice" and notes that they were not old, indicating that it was not time for them to die. "Misfortune" is mentioned to help the speaker accept their deaths. The second speaker uses the same rhetoric when talking about the university administration and faculty she read about (upper-class men, healthy, not old), saying that their deaths were unnatural and tragic. In a similar story about the death of a simple rural woman, the victim is also praised, but since she is neither a man nor an accomplished citydweller, the only thing she is praised for is her (relative) youth:

3) О го́ссподи, чу́єте яка́ прийшла́ ка́ра бо́жа тай гото́во | што людеิй як | каза́ли шчо та́ шчо | оди́н чоิлоิвік | бы́в деิсь у іта́ліі | та ві́н перехво̂рів | но тай перені́з_яко́́сь так і́хав сюды́ в че̂рнівци́х ... | a жінку надарова́в три́цьцять сім ро̂́ків тай поме́рла | но́ та я́ вам ка́жу тай молода́ | обь́чно ж то старі́ помира́ют а ту́й тоิбі́ на | тай біда́ тай біда́ |

[My God! See what a disaster it is [O hósspody, chúiete iaká pryishlá kára bózha, lit.: what kind of God's punishment has come], that people, as...They said one man was in Italy; he had COVID-19 and recovered and came here, somewhere in Chernivtsi, and gave it to his wife zhinku nadarováw]; she was 37 years old, and she died. I am telling you ... She was young; usually it is the old people who die, but here ... That is a misfortune, a misfortune [tai bidá tai bidá]] [Informant B, 21 March 2020].

"Misfortune," "no cure," and "what's to be done?" are invoked as devices used to accept the reality though still pointing out that it should not be so. COVID-19 is the apparent embodiment of destiny that cannot be fought.

Alongside stories about deaths from COVID-19, there are also disease and recovery narratives. I did not research disease stories in the pre-COVID-19 period, so that there is no basis for exact comparison. (6) However, the COVID-19 disease and recovery stories resemble death stories in their structure; specifically, "bad death of a good person" stories. The absolute majority of disease and recovery 
stories (I have collected over 60 stories of various lengths) are about a good person who tragically got sick and suffered greatly, sharing similar features with the "bad death" stories even if the person recovers. Below is such a story:

4) А бра́т | шо в [place name] | шо в на́с еле́ктриком | та ка́же обы́ бы́в им оди́н де̂́нь запізни́в ся | я́ быв там бы́в де мо́я ка́же сестра́ | i те̂пе̂́рь кае́ не ... но о́де ми каза́в | я́ шче ка́же півро̂́ку | не набе́ру ся си́лы яку́ я ма́в | а ві́н такы́й мо́цный такы́й | як се̂́сь | [describes the man I know] | но | такы́й здоро́вый чуе́те | ду́же шахмати́ст | ві́н ма́є i нагоро́ды бо ві́н бра́в у́часть | но | а са́м він хо́дит | [describes his work] | нó тốму ... póбит | дочка́ його́ перене́сла ле́хко | жі́нка тó же са́моє $\mid$ а ві́н ма́ло не пішо̂́в сь_сьві́та $\mid$ но | ка́же вы́дав ім до | до ти́сячу доิ́ларів но | тото́ у нас мно́го такі́ | на ліка́рства | но тай шо́ зроби́ти | шо́ зроби́ти коли чи ви́дите така́ біда́ прийшла́ та |

[And her [a woman who died of COVID-19] brother in [a village nearby], who works as an electrician, he says, "if I had been [taken to the hospital] one day later, I would be in the same place as my sister" [i.e. he would have died]. And now, he said to me, "It will take me half a year to regain my previous strength." And he is such a stout guy, healthy, as [another man both the speaker and I know]. Such a healthy guy, a chess player, he has awards, he took part in ... and for work, he [the speaker describes his work]. His daughter had an easier COVID-19, his wife also, but he "almost went away from this world". He says, "I gave them up to $\$ 1000 \ldots$ and there is a lot [of people] like this ... for the medicines." What can one do, if this disaster has come?] [Informant D, 17 October 2020].

The speaker mentions the man's achievements: the man has a job; he has an intellectual hobby (chess) in which he is accomplished (he has won competitions); he used to be healthy and stout (which are apparently roughly equivalent for the speaker). Nevertheless, he got sick with COVID-19 and, unlike his female relatives who had a milder case of the disease, he suffered both bodily (it will take him a long time to recover his previous health) and financially ( $\$ 1000$ is a lot of money; for comparison, a teacher's monthly salary is around $\$ 100$ ). Again, the feeling is that the man was undeservedly hard hit by fate. The speaker again blames the misfortune/disaster [bidá], a euphemism for COVID-19.

There is an additional wrinkle in the man's misfortune as well: a long recovery is required for him to be fit enough to do his job. In the culture of Novoselytsia, money earned on a job is not something vital (an entire family can live off their land and side earnings, such as gathering and selling berries in the summer), but earnings from one's job contribute to the family's welfare; while not earning drains family resources. A man who is not fit to do his job is a disgrace to himself; depleting the family budget and then still not being able to work adds 
insult to injury. This man then has been dealt an additional blow to his reputation. But, as the narrator says, there is little recourse: "What can one do if this disaster has come?"

The "bad disease of a good person" stories similar to this one that lament people's undeserved misfortunes constitute an absolute majority of disease narratives. I heard just one story of the type "bad disease of a bad person." Its main character was a man who had divorced the speaker's cousin after a long marriage and thereafter was considered an enemy of the entire family. He was said to have visited his old mother for Christmas, after which they both came down with COVID-19. The speaker summarized: "He must have been running around [vsiúdŷ shástaw], so he brought his mother the infection." The verb she chose to use [shástaty] could mean "walk, run, prowl around, skirr" or "be promiscuous." Apparently, the speaker conceives of the man's promiscuity as an essential trait of his character and sees COVID-19 as retribution for his misbehavior.

While only one of this type was documented, the stories where a good person suffered undeservedly were ubiquitous. They were told about relatives, fellow villagers, people living elsewhere in the region about whom the speaker heard from others, and about people from mass media sources. The pervasiveness of this story type leads to three comments about their social function. The first is that, by default, when speaking about matters of life and death, a person is considered to be in the "good" (or "our") group until proven otherwise. Even if a narrator holds minor grudges against a fellow villager, if they die or get seriously ill, survivors owe them a eulogy. The second comment is that the same treatment extends by default to the people the speaker has no personal knowledge of. When talking of people in other contexts, the first thing mentioned is always whether they are "from our village" vs. "not from our village," with the further distinctions between "our people" and "Poles" (i.e., people from the north of the Carpathian ridge) or between "from here" and "from Ukraine." However, all these distinctions become irrelevant when talking about death and disease. It is possible that speaking ill of a dead person incurs reputational damage for being hostile to the point of not following societal rules or invites retaliation by the spirits of the deceased, but this hypothesis requires additional research to determine which factor is more likely in this context. Thirdly, the only exception attested concerned the person who harmed the speaker's family. Below we will see in more detail how the family is at the center of values in Novoselytsia, but this brief story gives us a glimpse of the family-centered worldview.

\section{Stories of Spreading and Contracting Infection}

In addition to stories of death, disease, and recovery, there arose a new type of narrative that probably was not in existence before COVID-19: stories of spreading and contracting infection. In some of these stories, speakers talk about COVID-19 spreading after people came together for church, memorial services at home, weddings, etc. Usually, it is not known who the infected person was at the 
gathering. Speakers bemoan a number of people getting sick and conclude that it is dangerous to go to gatherings during these times. Below is an example:

5) А: ... коли́ пі́сьля кири́л та яко́є не̂шча́сьця бы́ло кі́лько тоิді́ бы́ло хво́рых | та хто́ дужы́й та | перебо̂ро̂́в вдо́ма | то го̂рячкы́ лікова́ли но a хто́ слабы́́ та $\mid$ та і в у́жго̂роิді лежа́ли бага́ті і̂́x і в міжгі́рі по̂́вно бы́ло і на́ші ...

Author: Тí шо приі́хали на кири́ла вони́ | хто̂́сь з ни́х прині́c?

A: Хтó $\mid$... хто̂́сь бы́в такый но̂сіє́м тай $\mid$ надарова́в тай всьо́ |... [name] ... cếi [name] | я́к вам ка́ти | сестрь́ доิчка́ | бы́ли сьме на кла́дбышчі бо у на́с сего̂дьні де̂нь па́мняті | а мы́ пішли́ поза́вчо̂ра | у че̂тве̂́рь та сьме там | диви́ли ся порри́док тадь ми́ так ча́с від ча́су ідемо́ | та чýєте та каза́ла за сво́го ба́тька в не̂́i ба́тько уже́ сімде̂ся́т пя́ть ро̂́ків маé | мо́же і бі́льше | тай ка́же | чи йоммý треá бы́ло іти́ тогды́ | на кьири́ла а да́льше пішо̂́в | доิ [name] савть́рю чита́ти тай | та до́бре шчо ско́ро | потра́пив в ліка́рню та врятува́ли го | так | мі́х ка́же | уже́ та́м быв бы тай таке́ шчо | як ра́з нам там каза́ла |

[A: After St. Cyril, (7) there was such a misfortune, so many sick people. The people who were stronger, they got better at home, cured these fevers, but those who were weaker ... And in Uzhhorod, there were a lot of them [in the hospital] and in Mizhhir'ia, a lot of them

Author: Among those who came for St. Cyril's, someone brought [the infection]?

A: Who ... there was one carrier, maybe, who infected others, and that was that. This [name of a woman], how can I tell you, her sister's daughter, we were together in the cemetery, because today we have a day of remembrance, and we went the day before yesterday, on Thursday, cleaning up there, we do it from time to time. And you know, she told us about her father, her father is 75 years old or older, and she said, "Did he really need to go to church on St. Cyril's Day, and then he went to [name]'s to read the Psalter [at a memorial service] and ... It's good that he was rushed to the hospital soon, so they helped him; otherwise, he could have been there already." She told us there [in the cemetery]] [Informant A, 1 November 2020].

Both events, the church service on St. Cyril's Day and the memorial service in someone's home, are important events in everyday life. St. Cyril's Day is considered to be the feast day of the church in Novoselytsia; strangely, the church is dedicated to St. Michael, and Michaelmas (8) is also celebrated as the church's 
feast day, but St. Cyril's is much more important to the congregation. On St. Cyril's, all natives living elsewhere try to come to Novoselytsia. They attend the church service, maybe go to the fair that takes place next to the church, and then visit their relatives, feasting and exchanging gifts. Coming to the village for St. Cyril's is a sign of belonging to the community. The second event mentioned in the narrative, the memorial service where several people read the Psalter and have a meal, is a necessary part of death rituals; it is done while the body is still in the house, then several more times at larger and larger intervals (ninth day, fortieth day, and one year after the death). It is important for the family of the deceased and a sign of respect for the readers who are invited to participate. The old man apparently could not miss any of these important occasions despite the risk.

The story of his getting COVID-19 at one of these events is constructed along the lines of the popular "getting into danger/having an accident" story pattern in Novoselytsia. That story type itself is reminiscent of a simplified version of Propp's pattern for the magic tale. The "accident story" includes: a description of the circumstances; maybe a premonition or a warning, overt or implied; an account of how the person did not heed the warning, perhaps unwittingly; and what happened as a result. Pre-pandemic, I recorded a large number of such stories. (9) The story about the old man getting infected has all the elements of an "accident story:" the explanation of the circumstances and the warning (in his daughter's words, in hindsight), how he went to both places, and how he narrowly escaped death as a result. Other stories about one person, or many people at once, getting infected also contain these elements and are apparently also based on the "accident story" pattern.

However, sometimes in the "getting infected" stories, the spreader is known, as in the story below:

6) I у нас | у ірша́ві | жі́нка | захвоิрі́ла бы́ла два́ дні́ чи три́ но вы́явили $\mid$ а вона́ всю́́ды ша́стала | і службб́ | і савтырі́ чита́ла | тай поме́рла сьогоिдьні в ра́ньці | а ї сы́н зав поิлікліникоิв в ірша́ві це | та то́же го надарова́ла | надарова́ла го чу́єте | но го́ре сяко́є тай гото́во |

[Here too, in Irshava, a woman got sick, [she was sick for] two or three days, and they figured it out; and they said she had gone everywhere, to services, read Psalter, and died this morning, and her son is head of the clinic in Irshava, so she infected [nadarovála] him as well, she infected him. That is a misfortune, and that is it]. [Informant C, 6 April 2020].

Another story concerns the speaker's family:

7) ... там | ті́тка і зя́ть і вну́ка і дочка́ | а ... тако́є | тó | вонá | се̂сь шчо воิдіе́м | лікарьку во́зит у [name of the village] | то лікарька бы́ла хво́ра тай то́же не бессо̂́вісна | она́ на нога́х переноси́ла | указа́ло 
їпозити́вноє | а оิна́ да́ле ходи́ла | ві́н ї вози́в | но тай надарова́ла го | та дару́є вам тото́ |

[... there [in the neighboring village] [the speaker's] aunt, and brother-inlaw, and [his] granddaughter, and daughter, [everybody is sick], and [what happened is that] she ... this guy [the speaker's brother-in-law] who is a driver, he drives a [female] doctor in [name of the village], this doctor was sick - isn't she without conscience? she was sick and continued working, her test was positive, and she kept going around, he was driving her, so she infected him, you can get infected this way] [Informant A, 13 July 2020].

The speaker directly blames the doctor who infected her cousin's family, and, later in the narrative, uses some strong words to describe her. However, other people told similar stories from a different perspective, namely about their relatives going to work when sick or after not checking their status when they had a sick person in the house. "They would have quarantined her for two weeks," one person stated in another story, "and who would work in the meantime?" [Informant D, midMarch 2021, exact date unknown].

These stories dovetail with the story of the old man in the village who disregarded the danger and went to church and the Psalter service, as well as with another story about a woman in Irshava who spread the disease at church and a memorial service. One might wonder why these people would take this risk. As I mentioned above, there are a number of values that are important for identity construction in the village. These values are intrinsic, and people who comply with them are entitled to feel good about themselves, whatever else happens in their lives. The main goal in one's life is to ensure that one's household - defined as one's house and the people in it - continues to exist and thrive. If the house remains empty, it is a disgrace and a disaster. Therefore, for example, if a couple has no children, they adopt a child and make sure that, upon becoming an adult, $\mathrm{s} / \mathrm{he}$ brings a spouse into the house, continues to work on the land, and leaves progeny who will continue to live in the house. Taking care of one's household and family is extremely important. A person who does not contribute, with their work or earnings, becomes a burden on their household, and it is a disgrace for them. Money is considered more prestigious than the work of one's hands, so two weeks in quarantine without salary is insulting, even if the family can afford it. Another value that is extremely important for a person's identity is their reputation in the community. Reputation is hard earned in a village where everyone knows each other. Being an avid church-goer and a reader at Psalter services boost one's reputation, and one does not reject those opportunities lightly, even in the presence of COVID-19.

In addition, as the pandemic continued, it became clear that not everyone who contracted COVID-19 would die of it. Contracting the virus and the severity of the cases are circumstances meted out randomly. Even good people get sick 
and die. There is nothing to be done, as different speakers continually mentioned, so that apparently one should not abandon normal activities that are important for survival and self-esteem, just because chances are higher than usual of getting sick and maybe dying or contracting the disease and passing it on. If someone passes on COVID-19 to their brother-in-law, they would be angry; if their old father recklessly goes about his business and gets infected, they might be annoyed as well; but if someone in your family continues working while sick or taking care of a sick family member, it is a normal thing; who would act any differently? In addition, death is not considered bad in and of itself. When life is organized around the survival of the family in its house, not around an individual's pursuit of happiness, then a person of any age feels good while s/he contributes to the family's wealth and bad if s/he does not. As a result, the elderly keep cows and pigs and do not listen to their children's advice to stop working so hard. They feel that they are providing for the family, because children who live in the city do not have to buy milk and meat, which are expensive. For this reason, an old and disabled person should feel that he depletes the family's resources and by all rights should be ashamed. Death would be a blessing for such a person, because he will not be a burden to his family; old and frail people often express this opinion about themselves, sincerely lamenting that they have been living too long. During the COVID-19 pandemic, many speakers have calmly summed up stories of death and disease: "I am old already. It will be okay for me to die; it is my children that I worry about because they need to raise and marry off their children." That is, after one's children are married off, one's purpose in life is achieved. At that point, death does not seem bleak and may be even attractive and timely when compared to being unable to care for oneself and requiring a lot of work, because that would harm the family's welfare.

On the other hand, a multi-generational house - with children, adults, and grandparents - where everyone, including the old, can contribute to the family's well-being, is a desirable ideal; people feel deeply troubled when something goes awry and this model cannot be implemented. During my research, I heard one story a number of times about a woman who died after contracting the virus at her son's wedding. Leaving aside the fact that this wedding had been a superspreader event, the fact that apparently fascinated and scared speakers was that a few years earlier, the woman's husband had died a week or so after their daughter's wedding. Below is one rendition of the story:

8) Та на то̂́му ве̂сі́лі всі́ підхопи́ли | молодо́го ма́ти | уме́рла | пі́сьля то́го у у | як | пі́сьля ве̂сі́ля рі́вно у два́ ти́жні | она́ до́ма | ти́жде̂нь бы́ла | півтора́ | ішчи́ походи́ла по чоิ́рні я́годы знае́те у ве̂рьху́ полно́ | яфи́ны ка́жуть | горря́чку ма́ла пи́ла які́сь табле́ткы то коло [name] оิна жи́є та́м де | ви́ у [name] бы́ли | а від [name] та́м | чýть чу́ть | піти́ | та́м де [name's] тáто | роิзуміе́те | вы́ коли́сь бы́ли там чу́ть чу́ть | а коли́ ї приве́зли | тоिді́ коли́ [name] [name] пізніше підхопи́ла | та | [name] шче мо́ж было урятува́ти | а оิна́ уже задыха́ла ся два́ дні | чи 
три́ пожи́ла тай поме́рла | пйяде̂ся́т три́ ро́ки | но | та де́ не шко́да го́ссподи | то та́к бо̂́ляче | коли́ | доิчку́ віддава́ла де́́сь ро̂́ків тоิму́ три́ чоть́ри | но тать чоิлоิвік ї напи́в ся та уме́р | через ты́жде̂нь | а оิна́ | си́на жени́ла то .... | но | і те̂пе̂́рь ха́ту замкну́ли | бо си́н шо жени́в ся се̂й | шо у ... сусі́дів брав ді́вчину та | ôни́ у че̂́хіi роби́ли тай по̂́іхали в че́хію | а ха́ту закры́ли | a | шче бы́ла ба́ба | pôзуміе́те | його ма́мы ма́ти | тай забра́ла ї | дру́га дочка́ в [name] райо́н |

[... Everyone got it [COVID-19] at that wedding. The groom's mother died after that, after ... exactly two weeks after the wedding. She was home for one and a half weeks. She even went to gather blueberries, there are a lot of them in the mountains, you know, they are called iáfyny. She had a fever; she took some pills - she lives (10) not far from TT [at the other end of the village from the narrator], a little towards TT's father's place, you have been there. She was taken to the hospital at the same time as TT, but TT got it [COVID-19] later, so she could be helped, and this woman was already short of breath. She lived two or three days and died. 53 years old. Isn't it a pity, my God! It's so painful ... [ta dé ne shkóda hósspody | to ták bốliache]. When she was marrying off her daughter, about three or four years ago, her husband got drunk and died a week later, and [now] she was marrying her son off, and [she died two weeks later]. And [their] house is locked up now. Her son married a girl from our neighbors' house; they worked in the Czech Republic, so they went back there, and the house is locked. There was also a grandma, his [the groom's] mother's mother; another daughter took her to her house in [name of] district] [Informant D, 17 October 2020].

This is a sad story ("isn't it a pity ... it is so painful") not only because the woman died having contracted the disease at her son's wedding, but because her house, instead of flourishing, stood empty. Her daughter's departure from home after getting married was expected and normal, but right aftewards, the woman's husband died, initiating a downward spiral for their household. The son, according to traditional rules, should have brought a daughter-in-law into his mother's house, but, because she died soon after the wedding, the newlyweds returned to the Czech Republic. Even the old grandmother was taken to another daughter's house in a different district of Transcarpathia. What should have been family victories led rapidly to the household's destruction: as the narrator comments, $\mathrm{Ta}$ dé ne shkóda hósspody [Isn’t it a pity, my God].

Stories about Politics

Besides stories about personal and vicarious experiences with COVID-19, speakers frequently and thoroughly discussed government measures directed toward the pandemic. (11) The main theme in these stories could be summed up 
in the phrase "our country is the worst." Some of these stories were structured as comparisons between the situation and policies in Ukraine and those in other countries - information speakers gleaned from friends living in those countries or from the media. Though the objective situation in Ukraine might be better than in other countries ("They say in Ukraine there are 42 [cases], seven are suspected, and in Italy, it is a disaster [bidá], one friend from Dolyna called me and said they had 700 or 800 cases [in Italy]," [Informant B, 21 March 2020]), Ukrainian policies are always portrayed as bad by comparison to other countries. One example of practices that are considered better elsewhere is mask wearing: " $\mathrm{A}$ friend in the Czech Republic said the authorities there were strict about masks, and here in Ukraine, people don't believe in COVID-19 and don't wear masks" [Informant A, 13 July 2020]. On other occasions, there was no comparison; the speaker would simply retell what $\mathrm{s} /$ he found out about the current situation in Ukraine and would vehemently explain why it was so terrible. Sometimes speakers would get so emotional that I would rapidly change the topic, frankly scared to see them in such distress.

Interestingly, when the situation with COVID-19 would deteriorate in another country, or when measures taken were less than laudable, speakers would not blame that country's authorities at all, or not as severely or emotionally as they would blame Ukrainian authorities. The same woman who reported her friend's words about wearing masks in the Czech Republic said in an interview a couple of months later:

9) D: ... шчоิсь у че̂́хіi бага́то хво́рых | вчо́ра ми звони́ла $\mid$ тай ся́к $\mid$

Author: Y че̂́xiі я́ ти́ж чýла шо ду́же бага́то те̂пе̂́рь [...]

D: Но те̂пе̂́рь | та ка́же та́к ся со ... | вро́де і сокоти́ли ся ка́же чи | куды́ в метро́ чи куды́ всю́́ды в ма́сках но і та́к тото́ ві́ткысь ся pôспоิвсюдило тай біда́ |

[D: For some reason, there are a lot of cases in the Czech Republic. She [a friend] called me yesterday.

Author: I also heard that in the Czech Republic there is a lot [of cases] now

D: Yes, now ... She said they apparently took care of themselves; in the subway, and everywhere, everybody was wearing masks, but for some reason it [COVID-19] got widespread, and that is a misfortune [tai bidá] [Informant D, 17 October 2020].

Later, when restaurants were closed in the Czech Republic, and the woman who told the speaker about obligatory mask wearing lost her job as a result, the speaker 
did not criticize Czech authorities; she only described her friend's job situation in detail [Informant C, 18 October 2020]. Earlier, in March, when Ukrainians were sent home from other European countries, according to the same speaker, she described the actions of these countries' authorities as brusque and inconsiderate, but did not use accusatory language:

10) ... тото́ ци ви́дите яка́ прийшла́ поิслі́дниця | така́ прийшла́ шо лю́ди як му́хы мру́т тай всьо́ тай | а доิ на́с їдуть та всьо́ бы́ло зароิбітьча́ни | іс україны | по̂́льшча іта́лія іспа́нія | те̂пе̂́рь то всьо́ ві́тты | всьо́ позакрыва́ли там каранти́н | і выту́рюют ги дурны́: | здôpốві чи хво̂́pi | іді́т сôбí | та знае́те а у на́с і те̂сьтів ниє | ниє чи́м тото́ ...

[Do you see what times have come, the end times [tsy vídyte iaká pryishlá pôslídnytsa]? So that people die like flies. (12) And everyone comes here [back home to Ukraine]. There were a lot of people from Ukraine who worked in Poland, Italy, Spain, and now everything is closed there, the quarantine, and they are sent out like stupid ones, whether they are sick or healthy, just, "you go." And we don't even have tests, nothing to do that with ...] [Informant B, 21 March 2020].

Sometimes the situation in another country was used only as a springboard and was not even commented on; the speaker immediately switched focus to Ukraine and blamed everything on Ukrainian authorities, which sometimes resulted in a series of loosely connected accusations:

11) В: Хворо́ба ця не | не пра́вит нико́го се́ така́ хворо́ба | а у ва́с ішчи́ є́ в аме́риці то́же?

Author: Y на́с є бага́то | бага́то шчи́ '́

В: Я чу́ю по телְеві́зорі і стати́стику ка́жут шчо шчи é | но і в на́с | чи то́ і наспра́вді є́ | чи то́т | іс ци́ми вы́борами | они́ | знае́те не дозво́лили | доิне̂́цькі луга́нські о́бласьці на́віть тоть́ шо не піткоิнтро̂́льні | обь́ не го̂лоิсува́ли бо та́м не піттри́муют се̂сю́ на́шу | но̂вý вла́ду но | i хто́ іх зна́є чи́ оิни́ шчоิсь | шо́сь мудру́ють_іс си́м | коิві́дом шчо | вели́ка бу́де стати́стика шчо мно́го хво́рых | шчо | де̂сь зо́на там | черво́на тай $\mid$ та́м не бду́дь_голосова́ти чи шчо́ вони́ хоิ́тят | не мо́жеме зна́ти тай гото́во шчоิсь то | до добра́ не́ йде | до добра́ не йде́ а краду́ть краду́ть я́ се ма́й серджу́ на тоิму шчо | чоิмý роскрада́ють но чоิмý | та мы́ бага́ті бы́ли | у де̂яно̂́сто̂му ро̂́ці де̂яно́сто пе̂́ршо̂му на пя́тоิму а те̂пе̂́pь ісьме чốpт зна́є на яко̂́му мі́сьці уже́ | і то́ всьо́ роิзікра́ли і ко́жный краде́ і ко́жный бере́ | хто́ при вла́ді та нажи́вать_ся тай | 
[B: This is a disease that doesn't make anyone better. Is there COVID-19 in America?

Author: Yes, still a lot

B: I've heard on television, and the statistics, that there is still ... And in Ukraine too, I don't know if it is true or not, with these elections, you know, they didn't allow, in Donetsk and Luhansk Oblast', even the districts that are under Ukraine, they weren't allowed to vote, because they don't support our new authorities. Who knows what they are doing there, something fishy with this COVID, so that there will be a lot of cases, many sick people, so there will be a red zone there and they won't vote, or there is something else they [the authorities] want, we cannot know that, and that is it. There won't be any good out of it, there won't. And they [the authorities] steal a lot. That angers me the most, why are they stealing, why? In 1990 or 1991, we were in the fifth place, that is, we had the fifth largest economy - among the republics of the USSR? in the world? and now devil only knows in which place we are. Everything has been stolen, and everyone steals, everyone takes, anyone who has any power, they line their pockets, and that is it] [Informant B, 11 September 2020].

Such accusations often literally repeat messages from anti-Ukrainian and proRussian television channels. Many speakers watch these channels, e.g., $1+1$ and NewsOne, whose agenda is shaped by their owners, the oligarchs Igor' Kolomoisky (1+1) and Viktor Medvedchuk (NewsOne). (13) Medvedchuk is known in Ukrainian media and blogs as kum Putina "the man whose daughter's godfather is Putin." (14) The agenda and tone of Ukrainian television merit additional research, particularly the prevalence of messages that foster negativity, discriminatory attitudes toward women and minorities, general disrespect for personalities, the rule of law, and the truth in general. These messages might serve the worst instincts of the population, but they also may be designed to undermine participation in civil society and democratic procedures. (15)

These issues did not arise during COVID-19 in particular. Similar messages have played on Ukrainian television for a number of years. They fell on the fertile soil of post-Soviet nostalgia, a topic that is worthy of further research as well. My previous interviews have revealed that people view the late Soviet period of the 1970 s-1980s as a time of prosperity that finally came after the poverty and suffering of the pre-war times and collective farm era, that is, their entire lives before that time. As one woman told me with pride about the 1980s, "Even mugs and bed sheets could be bought in a store, at times" [personal communication]. Collective farms and factories of that time had provided poorly paid, but stable jobs. The subsequent economic hardship of perestroika and the closing of collective farms and factories affected people's well-being and their self-image. 
Some organized quickly and went abroad to work in construction (men) or as caregivers (women) and sent money home. Others, however, did not dare to take this risk and held onto their jobs, especially if the jobs had once been well-paid and prestigious (teachers, doctors, or workers in the remaining factories). As a result, these people eventually became much worse off than people without an education or previous experience who were working abroad and sending plenty of money home, and their pride suffered greatly. Nostalgia for the seemingly idyllic Soviet times when everyone had a job and was happy (17) was combined with a feeling of learned political helplessness apparently widespread also in the Soviet and post-Soviet discourses of various other countries. (16) The attitude, pervasive in my interlocutors' narratives, is that everyone in a position of authority is a crook and a thief, that this is how the world works, and that they, the people, cannot do anything since they are simple peasants (or worse still, peasant women) who do not understand politics. In the interpretation of numerous postSoviet difficulties, these three components: the feeling of political helplessness, Soviet nostalgia, and media presenting contemporary life as a perpetual and unavoidable disaster, came together into a well-established discourse "Ukraine is the worst country ever." (18) Therefore, predictably, a continuation of this discourse during COVID-19 was "Ukraine is the worst country at fighting COVID-19."

In general, there is not much structure in discourse about Ukraine being the worst country; its episodes are merely stacked one upon the other but are not arranged in any specific order. The COVID-19 episodes also became incorporated and work as well as complaints about high gas prices or low salaries. This discourse seems to be self-perpetuating: once a speaker gets into this mode, $\mathrm{s} / \mathrm{he}$ continues adding new episodes, becoming more and more emotional at each step. I could never listen to it at length because the speakers rapidly grew markedly upset, prompting me to switch the topic. I still do not have a good explanation about the function served by this discourse. However, Atlani-Duault et al. [2015] offer one possible approach in their study of conspiracy theories on Frankophone Internet in relation to the H1N1 pandemic. They state that expressing ideas about global conspiracies online

bestows a comforting sense of legitimacy and gives both authors and their readers the impression of being able to transgress certain social taboos and thus escape from their feelings of impotence. In addition, the collective search for guilty parties creates a link among those who might once have nursed their fears and suspicions in isolation. [Atlani-Duault et al. 2015: 56]

Since discourse in Novoselytsia features similar topics, including the sense of political impotence ("they are in power, and we, what can we do?") as well as the "search for guilty parties" that usually follows invectives on television, the 
"Ukraine is the worst" discourse might provide speakers the desirable feeling of political importance and of "being in the know."

There is one theme in the "Ukraine is the worst" discourse, however, that seems to be more closely connected with the local value system. The episodes used in this discourse are typically descriptions of policies, past and present, and not stories about specific people. However, there is one mythologeme promoted on television that elicits personal responses: that Ukraine's very existence is endangered because people emigrate. It resonates because many people have younger relatives - children, nephews, nieces, and grandchildren-working abroad. Thus, after stating, e.g., that doctors are overworked and underpaid here in Ukraine, which is especially unfair during COVID-19, and that doctors have emigrated to other countries, speakers usually recall stories of their own relatives who have gone abroad and done well. Below is an example that includes and continues excerpt 1 :

12) В: ... таі лікарі́ | у [name] в [name of a town] два́ чи три́ лікарі́ уме́рли | на коิві́д сього́дні | сакі́ то спра́вы |

Author: Кі́лько уме́рло?

В: Маіже три́ | два́ або три́ лікарі́ |

Author: Бо́же

В: Но | тай такі́ шче | бо у фе̂йсбу́коิви ба́чила такі́ фа́йні чоิлоิвікb́ пі́т шизьдіся́т ро̂́ків шче̂ й не было шіздіся́т тай

Author: Бо́же

В: Тай шчо́ зроби́ти тай чи ви́дите біда́ то̂́ї біды́ $є$ до́ста тай гото́во $\mid \mathrm{a}$ ту́йкы чуе́те | пе́рше по р ... телеві́зоруу каза́ли та оิни́ i та́к бре́шут шчо се̂ре̂́дня зарпла́та лікаря у на́с у країні | де̂́вять ты́сяч | терпе̂́рь по | те̂ле̂візорру лиш каза́ли я́ кау́ най не | бре́шут бо о́де у міжгірью у [name] та | ші́сь с полови́ноิв сім | та хоิть хо́че обы ма́ла бі́льше | та бере́ нічні | ро́бит на ть́жню поิ дві́ три но́чи | уяви́ть соิбі́ лиша́й діти́ну лиша́й чоิлоิві́ка $\mid$ та роби́ $\mid$... | а у ни́х у ты́х слу́гів наро̂́дів наро̂́ду шо ка́жут | тай | у усьь́х ішче̂ ім те̂пе̂́рь підня́ли | проิкуро́рам судя́м | ты́м слуга́м всьы́м поюпіднима́ли по над де́́сять ти́сяч по над два́цьцять | a і та́к ма́ли по со́рок пяде̂ся́т ти́сяч | а шче̂ вся́кый бі́знес но тай шчо́ | у на́с ся не ці́нит | ро̂́зум абсоิлю́тно ни | ни оิсві́та ни медици́на | ни науко̂́ві ни́ч на нау́ку то́же не виділя́ют тай | шо́ бдут розроิбля́ти ке̂ть | нема́ іс чи́м з̧а́раз̆ вы́жити | тай сякі́ то спра́вы |

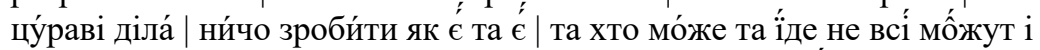
ви́їхати бо коли́ там $\mid$... коли́ сьте ба́чили мо́же | у ве̂че̂́рi | така́ $\epsilon$ 
переда́ча $\mid$ та та́м | оди́н якы́йсь є бізнесме́н охрі́менко такы́й борода́тый $\mid$ тай ка́же $\mid$ но $\mid$ до́бре $\mid$... най си зароิбля́ют $\mid$... до́бре він мáє б́́ззнес $\mid$ мо́ж жи́ти $\mid$ но а $\mid$ не ко́жный мо́же по̂́іхати | чи діти́на мала́ а як батькі́ нема́ чи батькі́ хво̂́рі чи шчó | но то я́к вь́їхати | но́ тай | не ко́жный мо́же так по̂́іхати обы там плати́ли | особли́во по̂́льшча че́хія слова́кія те̂пе̂рь ду́же мно́го | на́ші іду́т ї́дут | iз на́шого села́ уже там | і кварти́ру купи́ли і ви́селили ся ві́дсі тай всьо́ [...]. In [name of a village] ... | [name of a village] [female name] то́же чоิлоิві́к і оิна́ у слова́кіi | [name] до́чка | купи́ли там ха́ту тай там жи́ют соิбі́ но тай | зарпла́та | ві́н па́ру мі́сяц ... pốків пороби́в два́ чи три́ маши́ну | таку́ | до̂роิгу́ | купи́в ... я́ зна́ю якý | япо̂́ньську чи якý | но тай бốгу дя́ковати но абó $\mid$ усі́ так не мо̂́жуть по̂́іхати $\mid$... хто̂́сь ся i ту́й мае́ лиши́ти

[B: ... And doctors ... In [another district center in the region], where MM lives, two or three doctors died of COVID, today, that is how it is.

Author: How many died?

B: Maybe three, two or three doctors

Author: Oh my God!

B: Yes. And they were also ... I saw it on Facebook: such nice men, less than 60 years old, younger than 60 .

Author: Oh my God!

B: But what's to be done? Do you see, it is a misfortune, there is a lot of this misfortune, and that's how it is. And here, on the $r$... on television they said that a mean salary for doctors here was $9 \mathrm{~K}$ hrn [about $\$ 320$ per month]. Right now, they said it on television. I say, let them not lie, here in Mizhhir'ia, [a doctor the speaker knows] has 6.5 or $7 \mathrm{~K}$; and if she wants to have more, she works nights, two or three nights a week, just imagine - she should abandon the kid and the husband, and go work ... And these Servants of the People [the President's party], they all raised salaries for themselves: prosecutors, judges, all these "servants", 10K, $20 \mathrm{~K}$, and they did have $40 \mathrm{~K}$ or $50 \mathrm{~K}$ before and also owned businesses. Smartness is not valued at all here, neither education, nor medicine nor science, no money is given to science, what will they [doctors and scientists] develop if they have nothing to live on? Bad things [are happening]. Who can go, they go, but not all can leave because if ... Maybe you watched a show [on television], one Oxrimenko, such a bearded guy, said there "let them go and earn". It is good for him, he has 
a business, but some have a little child, and they have no parents [to babysit their child] or their parents are sick. How would they go? Not everyone can go and earn. Poland, the Czech Republic, Slovakia; many people from our village are there, some bought apartments and left permanently from here [...]. In [name of a village], [a niece]'s daughter is in Slovakia with her husband; they bought a house and they live there, and the salary...he worked for a couple of mon ... years and bought himself an expensive car, Japanese or something, I don't know exactly. Thank God for that [no tai bốhu diákovaty], but not everybody can go; someone needs to stay here] [Informant B, 22 December 2020].

Just after the story about doctors' travails, the speaker offers a litany about the corruption of the president's party and how it disregards the interests of citizens and the state. Then the speaker switches from the state's perspective to the people's perspective and quotes a television show that apparently resonates with her personal experience. She does not disagree that going abroad temporarily to earn money is generally a good thing, but not everyone can arrange her/his life to make it happen. Then it turns out that many people from the speaker's village are working abroad or permanently live there, including her own niece's daughter and son-in-law. This shift of perspective, from country to village and then to family also changes the assessment of the fact that people go abroad to work and live. From that perspective, it is constructed not as a disaster for the state, but as a success ("Thank God") for the speaker's extended family. The subsequent phrase "not everybody can go" sounds almost like a regret that the speaker's own children and grandchildren could not also go abroad to make their fortune as her niece's daughter had.

This story also demonstrates the clash between two sets of village values reflected in the two discourses. On one hand, according to the traditional worldview, when people move out of the village, it is bad, because they leave their houses empty, effectively destroying the center of the village value system, the household. That might explain why speakers subscribe to the television maxim that soon Ukraine will be uninhabited; they see (and fear) the depopulation of their village, and it is easy to accept that the same is happening across the country. On the other hand, the success of their family is of paramount importance, so that going abroad is understandable and acceptable. It is noteworthy that the two discourses, one about the country's supposed ruin, and the other about family success, are equally attractive. People will talk at length about either topic.

Therefore, in the discourse about politics, we see that COVID-19 stories, like other stories of hardship, are used to prove a point, mostly in the "our country is the worst" discourse pattern. This discourse pattern has been around for decades, and COVID-19 stories, same as other stories of collective misfortune, fit well into the theme. However, the apocalyptic doom and gloom of this discourse can be mitigated by switching from a political perspective to personal perspectives about family values. 


\section{"The End Times Have Come": The Supernatural in COVID-19 Stories}

Do COVID-19 narratives invoke apocalyptic connotations outside of political discourse? I should reiterate that the women interviewed for this article do not belong to the generation that offers supernatural explanations for the majority of events in the world around them. Interviewees were reluctant to attribute supernatural causes for current events or their implications. However, a number of allusions to the supernatural, including descriptions of COVID-19 times as the end times, euphemistic constructions to describe death, and appeals to supernatural forces, did occur in the language of the stories.

The "end times" were mentioned more commonly at the beginning of the pandemic, in March and April, when general confusion, fear, and uncertainty were the prevailing moods both in the U.S. and in Novoselytsia. Below is an example of this expression in a narrative that was partially cited above in excerpt 10 :

13) В: ... тай сякі́ спра́вы | но́ та кажі́ть най вам шо̂сь ка́жу по́кы шче̂ жи́ю

Author: Ой бо́же, мій не кажі́ть так

В: А тото́ | лье́на то ни́хто не знае́ до́кі | доิкі живе́ тай всьо́ тото́ ци ви́дите яка́ прийшла́ поิслі́дниця | така́ прийшла́ шо лю́де як му́хы мру́т тай всьо́ тай | а доิ на́с ї́дуть та всьо́ бы́ло зароิбітьча́ни | ic україны | по̂́льшча іта́лія іспа́нія | те̂пе̂́рь то всьо́ ві́тты | всьо́ позакрыва́ли там каранти́н | і выту́рюют ги дурны́х | здо̂ро̂́ві чи хво̂́рі | іді́т сôбí | та знае́те а у на́с і те̂сьтів ниє́ | ниє́ чи́м тото́...та де́́cь каза́в ми пе́рше [name] шчо | аж їм у [name of town] да́ли два́цьціть , пя́ть те̂́сьтів но тай шчо́ | тай сяко́є | такі́ то бі́ды | а і́ншого то́же ниє́ ліка́рства тай | здоิро̂́ві ... выжива́ти та́й | кажі́т ми мо́же на́й вам ішче́ да́шчо ка́жу

[B: ... So ask me. I'll tell you something while I still live.

Author: My God, don’t say that!

B: That is, Lena, no one knows how long they are going to live. Do you see what came? The end times have come. So that people die like flies [tsy vídyte iaká pryishlá pôslídnytsia | taká priishlá. shcho liúde iak múkhŷ mrut tai wsë tai]. And everyone comes here [back home to Ukraine]. There were a lot of people from Ukraine who worked in Poland, Italy, Spain, and now everything is closed there, the quarantine, and they are sent out like stupid ones, whether they are sick or healthy, just, "you go." And we don't even have tests, nothing to do that with ... And we don't have tests, nothing, [a doctor from a different town] told 
me that they got 25 tests in [that town]. These are the misfortunes, and there are no drugs either. The healthy will survive, and ... Okay, ask me, let me tell you whatever else you need to know] [Informant B, 21 March 2020].

The speaker begins her narrative half-jokingly ("while I still live"), but then expresses her concerns: there were no drugs against COVID-19, not enough tests, and many people were coming back to Ukraine from other countries, often infected with COVID-19. All that taken together indicated a significant threat, the likes of which she might not have encountered before. However, her tone during this discussion was calm; she sounded concerned but not scared. She was serious about the perspective that people were dying "like flies" and that she and her family members might die too. I cannot assess whether she actually believed that it was the end of the world, but the choice of the word pôslidnytsia was suggestive of a dire situation.

An explanation about the connection between a word and a belief is in order. During my previous fieldwork in Transcarpathian villages, I noticed several stages of deterioration of supernatural beliefs. A belief is in its most viable form when a speaker can recognize it by a name or a key expression, explain what it involves, and tell a story (e.g., vôwkún "werewolf" produces an explanation that it is a man who can turn into a wolf, and a werewolf story; the expression hróshi po hórakh horriat"money burns in the mountains" elicits an explanation and a story about robbers' hidden treasures). The first stage of deterioration is when a speaker cannot tell a story but recognizes a key expression and remembers a belief. (NB: It is an entirely separate issue whether, and to what extent, a speaker believes in what he describes.) At the second stage of deterioration, a speaker knows only the keyword, often as a derogatory term (e.g., vôwkún or starŷi vôwkún denotes an unsocial person or a miser) but does not know the supernatural content associated with the word. Finally, the word ultimately might disappear from speakers' memory entirely.

Prior to my discussions on COVID-19, I had the sense that my interlocutors were positioned between the first and the second stages described above. Our conversations in previous years demonstrated that they had heard some, but not all, beliefs that their mothers and elder sisters engaged with. They themselves knew a few belief stories, but often could only state that they had heard the keywords or occasionally give a brief description of a supernatural entity. Concerning their own beliefs, they did not express them openly, and my impression was that they were not sure of the truth status of their stories themselves. They would often conclude a supernatural narrative with a phrase such as "and who knows if it was this way or not."

My interlocutors were well-versed in the art of warding off bad luck. For example, one of them taught me not to say, "I will arrive," but rather "my bus is scheduled to arrive" to avoid jinxing myself. On another occasion, a relatively young woman refused to talk about evil spirits because it was already after sunset. 
She said she would be "scared at night" if she did; I was not sure if she was afraid of dreaming of these spirits or of summoning them unintentionally. This expertise in appeasing destiny or other unseen forces through some kind of verbal etiquette also manifested in my interlocutors' speech during our COVID-19 interviews.

However, referring to the pandemic as "the end times" is nearly the opposite of what people do when they avoid talking about a supernatural entity or use euphemisms to avoid speaking its name. Calling the pandemic "the end times" is a direct, and daring, disclosure of one's picture of the world. Even if the speaker does not quite believe it, she inherited this picture from speakers before her. On the other hand, older women's ideas of the end of the world, recorded in Novoselytsia in the years before COVID-19, were much more elaborate: they included the cause ("because of our sins"), an exact roadmap of how the world would end, as well as who would be saved and how. This speaker, confronted by the reality of the pandemic, does not want to expound or gloat in this way. She does not mention even the idea of the pandemic as retribution here, let alone providing details of what or how it is supposed to happen. She has heard of the older generation's comprehensive idea of the end of the world, which she quotes in another interview, but nevertheless she distances herself from her mother-inlaw's point of view:

14) Author: Давно́ бу́ли які́сь роска́зы |... яка́сь чума́ ци бу́ли ци коре́ла ци шоิ́сь тако́є?

А: Но та бы́ла | го́ссподи | ти́ф быв | каза́ли ти́фус | шо тото́ | але не каза́ли | но та не да́й бо́г бы сcé уже́ те̂пе̂́рь бы́ло | но ма́ма [husband's name] каза́ла ка́ старі́ лю́де каза́ли | шо при́йде така́ хворо́ба невы́лікована | шо бду́т лю́де | як му́хы вме̂ра́ти | бду́т ме́рти па́дати тай всьо́ | но тай чуе́те те̂пе̂́рькы бо́х його́ зна́є чи то́ та́к чи не та́к | шчо | і ліка́рства шче нема́ i | поме̂ра́ють і | шчо́ тото чи́м то ся кінчит | стары́х но або вро̂́ді ка́жут шчо | ма́й на стары́х а молоды́х не бере́ | шчо моิлоิді́ лиша́ють_ся | ... чу́ла | но давно́ мно́го бы́ло | вся́кі бы́ли хворо́бы | лише май давно́ шчо | ме́рли | у ме́не то́же | у мо̂́ї ба́бы по ма́мині лінії | та на ти́ф | такі́ два ле̂гіні́ поме́рли | шчо лікова́ти не мо́ж было | а у [husband's name] сестра́ тота́ шчо | в [village name] | так вна́ захво̂рі́ла на ти́ф та | сьві́чку ї пали́ли шо уже́ уме́рла | та оิна́ вы́жила але на | да́ло ї на слу́х

[Author: Did people tell stories about plague or cholera, or something like this?

A: Yes, there was typhus [tyf] [after WWII], they called it týfus, and God forbid it comes now! My husband's mother said, old people told that there would be a disease without a cure, people will die like flies, they will fall and die. And now, you know, God knows if it is like this or not, 
there is no medicine yet, and people die, and how will it end? Old people ... they say it [COVID-19] affects older people more, not the young ones, so that the young ones remain. I've heard ... Long ago there was a lot of diseases, all kinds of diseases, in more distant times, people died. In my family too, my maternal grandmother's children, two young guys died of typhus, there was no cure. And [my husband's] sister, the one who is in [village name], she got sick with typhus, and they already lit a candle for her, they thought she had died, but she survived, only her hearing was affected] [Informant A, 20 March 2020].

The speaker compares the features of her mother-in-law's apocalyptic prophecy with those of the current pandemic. While she finds similarities, she is not eager to equate the two nor to draw similar conclusions. She then drops the topic of the end-of-the-world pandemic and returns to the topic of the typhus pandemic after (or during) the war, telling stories both about death and about recovery. The apocalyptic prediction is not applicable to her experience. While she uses the traditional word pôslídnytsia "the end times." in example 13, and the concept of a "disease without a cure" that old people had talked about in example 14, it has a different sense for her than for the older generation.

\section{Euphemisms}

Making words taboo is a familiar tactic in supernatural discourse. The examples above illustrate two instances when this technique is used. Speakers might want to avoid summoning something bad that might hear them and materialize if they say its name (e.g., the speaker did not want to talk about evil spirits after sunset to prevent contact with them). Alternatively, they might want to avoid jinxing something good which might happen if it is named directly (e.g., do not boldly state that they will arrive at a designated time because something might hear them and, out of spite, cause the bus to malfunction or stage an accident, punishing their hubris by preventing them from arriving). The same tactics of verbal etiquette in regard to the supernatural were used by speakers when talking about COVID-19.

Euphemisms to describe death were particularly prevalent in COVID-19 narratives. These examples include those cited above and others from my database:

15) Та до́бре шчо ско́ро | потра́пив в ліка́рню та врятува́ли го | так | міх ка́же | уже́ та́м быв бы тай таке́ шчо |

[It's good that he was rushed to the hospital soon, so they helped him; otherwise, he could have been there already] [Informant A, 1 November 2020]. 
16)| Та ка́же обы́ бы́в им оди́н де̂́нь запізни́в ся | я́ быв там бы́в де мо́я ка́же сестра́ |

[He says, "if I had been [taken to the hospital] one day later, I would be in the same place as my sister" [i.e., he would have died]] [Informant D, 17 October 2020].

17) Дочка́ його́ перене́сла ле́хко | жі́нка то́ же са́моє | а ві́н ма́ло не пішоิв сь_сьв́іта |

[His daughter had an easier COVID-19, his wife also, but he "almost went away from this world"] [Informant D, 17 October 2020].

Several aspects of usage are noteworthy here. First, death is only euphemized when people are talking about deaths that could have happened but did not. In these cases, they often use verbs in the subjunctive mood. When people did die, the verb pome/r(la) "died" is used rather than a euphemism. In close calls, death should not be named, likely to avoid bringing about a similar situation in the future.

Second, it is not the process of dying nor its result that is euphemized when a person is still living. Rather, speakers avoid mentioning the place where people end up after death. They describe it using evasive constructions: "there," "where my sister is" (she had died shortly before), or "away from this world." These expressions convey not the Christian paradise or hell, but the traditional otherworld, bleak and active, able to hear its name and come claim a person who has narrowly escaped it once. However, speakers apparently do not think of it overtly in these terms. They know the verbal etiquette for using a euphemistic expression that, when used correctly, will prevent misfortune. This situation resembles the second stage of belief deterioration: when only the word or phrase, together with the syntactic and pragmatic rules for its use, remain.

Death is not the only focus of euphemisms; the disease itself is as well. One would suspect that speakers would, first and foremost, avoid naming infections such as COVID-19 in order not to attract the disease. However, that is not the case in Novoselytsia: the verb zakhvôr'iw/-ila "got sick" is often used, although the elaboration na kôvid "with COVID-19" is sometimes omitted. Yet speakers relied on a euphemism to describe transmitting the disease: nadarováty "to give" (as a gift), as in this example that was partially quoted in example 3 above:

18) B: О го́ссподи чу́єте яка́ прийшла́ ка́ра бо́жа тай гото́во | што людеิй як | каза́ли шчо та́ шчо | оди́н чоิлоิві́к | бы́в де̂сь у іта́ліi | та ві́н перехвоिрі́в | но тай перені́з_ яко̂́сь так і́хав сюды́ в че̂рнівця́х ... | а жі́нку надарова́в три́цьцять сім роิ́ків тай поме́рла | но́ та я́ вам ка́жу | тай молода́ | обы́чно ж то старі́ помира́ют а ту́й тоิбі́ на | тай біда́ тай біда́ | 
Author: То ві́н приїхав і вона́ від ньо́го підхо́пила то?

В: Від ньо́го зарази́лася і оิна́ поме́рла |

Author: Боже

В: Но | ци го́ре сяко́є | та ві́н приі́ххав ма́ло бы́в хворякува́тый тай прійшло́ тото́ йомý $\mid$ a $\mid$ a í надарова́в тай | тай і сяко́є тото́ |

[B: My God! See what a disaster it is [lit.: what kind of God's punishment has come], that people, as ... They said one man was in Italy; he had COVID-19 and recovered and came here, somewhere in

Chernivtsi, and gave it to his wife [zhínku nadarováw]; she was 37 years old, and she died. I am telling you ... She was young; usually it is the old people who die, but here ... That is a misfortune, a misfortune.

Author: So, he came, and she got it from him [voná vid nióho pidkhópyla to]?

B: She got it from him, and she died [vid nióho zarazýla sia $i$ voná pomérla].

Author: My God!!

$\mathrm{NN}$ : Yes, you see it is such a misfortune. He came, he was a bit sick, and then he got over it, and he infected her [a i nadarováw] and that was it. That is how it is] [Informant B, 21 March 2020].

The speaker first used the euphemism nadarováw. When I did not quite understand her, she shifted to using a phrase which employs a literary Ukrainian word: vid nióho zarazýla sia [she was infected by him]. When she continued with her story, though, she repeated the euphemism. Apparently, it is important for her, and for other speakers, to depict the process of transmitting disease as passing on something benign, possibly in order to metaphorically lessen the threat of the illness for a (potential) "receiver." (19) This usage likely did not emerge with COVID-19, but oddly, I could not find any indication of its existence in dictionaries of adjacent languages and dialects. The verb nadaruvaty/nadaryty is attested in literary Ukrainian in the Slovnik ukraïns'koï movy [Dictionary of the Ukrainian Language] [1970-1980] and in Hrinchenko's dictionary focused on Western Ukrainian [1907-1909], albeit with a different imperfective formant, nadariaty/nadaryty). Both dictionaries present the meaning "to give as a gift," but not "to transmit a disease." Neither is this meaning mentioned in the Slovak online dictionary [Slovník.sk], nor in Pyrtei's Lemko dictionary [1986] nor in Onyshkevych's Boiko dictionary [1984], though the word is attested in all three. The word itself is not attested in two Transcarpathian dialectal dictionaries, 
Nikolaev and Tolstaia [2001] and Sabadosh [2008], or in the two-volume Rusyn phraseologisms [Chori 2015a, 2015b]. Either the authors of these dictionaries systematically skipped the euphemistic meaning, or this meaning is a local innovation, at least in the dialect of Novoselytsia. In addition, there is a euphemism, attested once, for being predestined for a more severe course of the disease:

19) Хто́ перено́сит ле́хко но та | кі́лька дні́в температу́ра пи́в антибіо́тикы тай прійшло́ | а кого́ шчо̂́сь полюби́ло | та ду́же тя́шко

[Some had it in a mild form, just a fever for a couple of days, they would take antibiotics, and everything would be all right, but those who were predestined [lit.: loved by something, kogo shchos' poliubilo] had it real hard] [Informant C, 18 October 2020].

Overall, although traditional village culture has a concept of actively transmitting a disease to someone (e.g., people transmit "crying" from one's baby to another by pouring water from the baby's bath onto the spot under someone else's window where light from the room reflects on the ground), (20) the concept of contracting the disease from a contact who does not mean evil, without taking any material objects from him is more of a modern medical one. Thus, established verbal patterns of behavior to protect oneself from catching disease may not exist. However, this hypothesis requires more research to make any definitive conclusions.

"If God Grants it": The Role of God in Discourse

The last aspect of the supernatural in discourse about COVID-19 relates to patterns that speakers use when mentioning God. In general, none of my interlocutors are overtly religious. I did not ask them about their religious beliefs or practices. Our conversations revealed that they went to church only for important feast days, because everybody was supposed to be there. However, unlike older women, they never mentioned anything about praying or reading religious literature, talked about any stories from the Old or New Testament, or went to additional prayer meetings organized by the church. Most of them grew up during the Soviet era when it was risky to take children to church. As a result, church culture is not in their active repertoire today. Therefore, mention of God is all the more interesting, especially in the context of the pandemic.

There are several set expressions referring to God (boh) in my interlocutors' speech, and God is mentioned only in the context of these expressions. The expressions are: "God knows" (to indicate uncertainty), "Thank God" (when talking about a positive occurrence), "God forbid" (when a potential danger is mentioned), and finally, "God gave that ..." (about some unexpected, usually good, event in the past) and "(If) God grants that ..." (talking about future plans 
or wishing for something good). If the first two expressions are more straightforward, "God forbid" is apparently used as a euphemistic-like device, e.g., in the context "they keep it [the blessed water]; they use it when, God forbid, there is thunder and lightning" [Informant B, 11 September 2020]. In essence, when naming something dangerous, the mention of God will prevent this dangerous event from coming to pass. In the same vein, the expression "(If) God grants ..." is used to prevent something good from being jinxed (as discussed above). The two instances attested are both about a living person:

20) Но і́ те̂пе̂́рь бу́де уже́ весноิ́в деิвяно́сто ро̂́ків | коли́ бы бог да́в

[She will be 90 in spring, if God grants that] [Informant A, 1 November 2020].

21) Дасьть бог шчо а ну ж | ке̂дь бдеме́ жи́ти обы́ нас лише́ [laughs] ковід не вы́мучив бо ка́жут шо | зно̂́ву дру́га хвы́ля а шче̂ по̂́тім які́сь | тоты́ гри́пы | но та | [laughs] мо́же шче̂ і не буде тре́ба як ка́жут | нас вы́душать тоты́ вся́кі хворобы́ тай гото́во |

[I offer to send some medicines in the mail. D refuses] Maybe then [when you come], if God grants that we live, if COVID does not kill us [laughs], because they say, there will be the second wave and also various kinds of flu... [laughs] maybe we'll be dead, and that will be it] [Informant D, 17 October 2020].

In both situations, when a person approaches her ninetieth birthday, and when there is COVID-19 around, life is not guaranteed even if sincerely wished for. Invoking God is an effective and appropriate protective measure for these situations.

Conclusion

This examination of storytelling and linguistic patterns in COVID-19 stories from Novoselytsia told by women in their forties, fifties, and sixties does not reveal any new genres or emergent story types. On the contrary, COVID-19 narratives fit well into older storytelling patterns. They are constructed along the lines of existing story patterns about deaths and accidents. In the context of the pandemic, narrative patterns adhere to long-standing structures, both in stories about people and in stories about politics. The stories express the same village values and cultural models as before COVID-19. Namely the household is the center of the world, one's personal worth is subordinate to the worth of the household, and satisfaction results from following this cultural model and contributing to household vitality. COVID-19 introduced greater levels of danger but served as insufficient motivation to abandon or significantly change behavioral 
patterns that made life meaningful. The same is true for the usage of euphemisms for protection in the narratives themselves. However, a thorough examination of COVID-19-era narrative and linguistic patterns allows for a deeper understanding of the village's cultural models and language expressions and their persistence, even in the face of social and medical crises.

\section{NOTES}

1 Novoselytsia is a village in the Mizhhir'ia district, Transcarpathia Region (Zakarpats 'ka Oblast'), Ukraine, in a mountainous area 475 meters above sea level and about 25 kilometers away from Mizhhir'ia, the district center. According to the census of 2011, Novoselytsia had 1054 inhabitants. Since there are not many jobs available in the village, the population mostly survives off their land; they have gardens and keep cows, pigs, and chickens; some also keep sheep or goats that are herded in the mountain meadows in summer. In order to earn money, men may go abroad to work as builders.

2 The literature on East Slavic folklore that I could find devotes little attention to good deaths, cf. long paragraphs about "bad deaths" followed by a few cursory sentences about "good deaths" in Slavianskie drevnosti [Tolstoi 2012: 61] subject Smert' [Death]. However, by examining the features of a bad death, or the death of a witch, one can glean some characteristics of a good death: a bad or a magical person dies a difficult death [Vinogradova and Levkievskaia 2010: 107-120 - Witches, 306-320 - Wizards, 326-328 - Females who performed magic [Koldun'ia]]; therefore, a good person must die an easy death. Some features of a "good death of a good person," as well as of a "bad death of a good person," can be found in funeral dirges (e.g., Barsov [1872] and Tolstaia [2019: 292]), where the image of the deceased is constructed by the speaker/singer as an image of a good person, but this warrants further research.

3 Cf. Vinogradova and Levkievskaia [2010: 107-116, 118-120]; literature listed on page 107 and also more broadly on witches on page 39 .

4 Concerning pre-COVID-19 deaths, though a supernatural explanation usually crystallizes in narratives within several days after the death, sometimes people have dreams about the deceased months or years after the actual death. These dreams sometimes change the perception of the deceased person and of their death from an unfortunate accident to a deserved divine retribution or vice-versa.

5 Because the dialect of Novoselytsia has not been codified, I have used Cyrillic phonetic transcription in block citations. Transliterations use the Library of Congress system for Ukrainian as much as possible, but I have included phonetic transcription for sounds not reflected therein.

6 Surprisingly, there is not much in literature on third-person stories about illness; anthropologists' attention has been devoted to first-person stories (along the lines of Kleinman 2020[1988]) or stories of parents and relatives of a patient [Price 1987; Jacobsen 2012], or both [Good 1994; Izquierdo and Johnson 2007]. 
Third-person illness stories are studied mostly by folklorists if they include supernatural elements (as fabulates or memorates); otherwise, they tend to fall through the cracks.

7 St. Cyril's Day does not have a fixed calendar date; according to an explanation I was given by one of my interlocutors, St. Cyril's is held on the Sunday that follows St. Peter's. St. Peter's is always held on 12 July; if it falls on a Monday, Tuesday, or Wednesday, then St. Cyril's will be held in the same week; if St. Peter's falls on a Thursday or a Friday, then St. Cyril's will be held on the following week.

8 Michaelmas is celebrated on 21 November.

9 See detailed transcriptions and translations of several accident stories from Novoselytsia in Boudovskaia [2017]: example 14 - a woman getting food poisoning; example 19 - a woman getting crushed by sacks of flour in the bakery; example 20 - a pig nearly biting off a baby's nose.

10 The speaker uses the present tense as if the woman were still alive in her house. It was not a slip of the tongue: on the recording there is no hedging or hesitation. I understand it as one more indication that a house and its inhabitants form a unity in the speakers' system of cultural models: if the house is still there and not occupied by another family, it still belongs to the woman, the head of the household after her husband's death, though she also had passed away several months before.

11 As mentioned above, such stories are not commonly perceived as folklore. However, I believe that they are an important genre in the system of Novoselytsia's oral narratives. They are opposed to, and counterbalanced by, personal and third-person experience stories; they have their own structure and purpose (see below), and they are especially prominent among the COVID-19 stories I collected. Finally, they, like other oral genres, shed light on the system of the village's cultural models. Therefore, I include them here.

12 The expression "people die like flies" [liúdy iak múkhŷ mrút] may seem to have an apocalyptic ring to it, but it is a common expression well known in East Slavic languages, cf. Rusyn liude - ne Siati dukhy: vmyravut', iak mukhy [people are not Holy Spirits, they die like flies] [Chori 2015a:421]; mrut', iak mukhy voseny [die like flies in the fall] [Chori 2015a: 452]; Ukrainian iak mukhy hynuty, merty [to die like flies] subject Mukha [Phraseological dictionary of Ukrainian online]; Russian mrut kak mukhi [die like flies] attested by Dal' [1863-1866] under the entry meret' and also in Gogol's Dead Souls [1842: 6] and in Dostoevsky's The House of the Dead [1862: 17].

13 See, for example, the material on Deutsche Welle 2020.

14 Kum is considered to be a very close degree of relationship both in Russia and Ukraine. Medvedchuk maintains his image of Putin's close friend and confidant (see 112 Ukraïna 2019). He also promotes a pro-Russian agenda on his television channels. 
15 While this article was in progress, some of these television channels specifically belonging to Medvedchuk (112 Ukraïna, NewsOne, ZIK) were banned in Ukraine by President Zelensky's decree of 2 February 2021, cf. Ukraïns'ka Pravda 2021.

16 Cf. "The radiant past" narratives in Paxton's description [2005] of a Russian village and "Yugonostalgia," e.g., in Macedonia [Chajęcka 2015] to name a few.

17 Ukraine is not unique in this regard. This attitude is characteristic of other post-socialist countries as well. Cf. "litanies" in the post-Perestroika Moscow [Ries 1997] and similar views and discourses in Poland [Pine 2002].

18 The role of post-Soviet television and other media in fostering these attitudes should not be underestimated. Research on the effect of media on public views shows that "on-going [sic] repetition of threatening information may increase fear and confusion, recalling the traumatic symptomatology associated with prolonged exposure to vivid and frightening images [...]. Moreover, threatening information can undermine public trust in media and government institutions if these are perceived to be overdramatizing minor risks or helpless to respond to them [sic]" [Atlani-Duault, et al. 2015: 44.]

19 Cf. nagradit' bolezn 'iu, lit. "to award with the disease" in Polissian texts (iak tu sawku stre 'tysh, to mozhut' khoroboiu nahradyty [if you meet this rusalka, they [sic] might give you a disease] [Vinogradova and Levkievskaia 2012: 577], Brest Oblast $^{\prime}$ ) and in multiple examples from the Russian-language Internet as well, e.g., Za nedeliu kleshchi "nagradili" 5 smolian bolezn'iu Laima ... [In a week, ticks gave Lime disease to 5 inhabitants of Smolensk] [Rabochii Put'2020], khoziain mozhet "nagradit"” bolezn'iu svoego domashnego liubimtsa [an owner can give a disease to his pet] [Vorobieva 2020].

20 This is a pattern known in the Carpathian area and beyond: see Agapkina [2019] for treatment and a list of literature on this topic.

\section{BIBLIOGRAPHY}

112 Ukrä̈na. 2019. "Путин крестил дочь Медведчука по просьбе его жены, Оксаны Марченко" [Putin baptized Medvedchuk's daughter by the request of his wife Oksana Marchenko]. 112 Украӥна. Cited by https://112ua.tv/obshchestvo/putin-krestil-doch-medvedchuka-po-prosbeego-zheny-oksany-marchenko-496517.html. (consulted May 29, 2021).

Agapkina, T. А. 2019. Агапкина, Т.А. "Параллели в области вербальной магии у восточных и южных славян." [Parallels in verbal magic among Eastern and South Slavs]. S.M. Tolstaia, ed. C. М. Толстая. Славянские архачческие ареальы в пространстве Европы [Slavic archaic areals in Europe] Москва: Индрик, 10-39. 
Atlani-Duault, L., A. Mercier, C. Rousseau, P. Guyot, and J. P. Moatti. 2015. "Blood Libel Rebooted: Traditional Scapegoats, Online Media, and the H1N1 Epidemic." Culture, Medicine and Psychiatry 39 (1): 43-61.

Barsov, E. V. 1872. Барсов, Е. В. Причитанья Северного края, собранные Е.В.

Барсовым. Часть І. Плачи похоронные, надгробные и надмогильные. [Laments of Northern Russia, collected by E. V. Barsov. Part I: Funeral Laments over a coffin and over a grave], Москва: Современные Известия. Boudovskaia, Elena. 2017. "Past Tense in the Rusyn Dialect of Novoselycja: Auxiliary vs. Subject Pronoun as the First- and Second-Person Subject." Journal of Slavic Linguistics 25(1), Winter-Spring: 3-62.

Boudovskaia, Elena. 2018. "Witches, Wise People, and Werewolves: Traditional Supernatural Powers and Popular Attitudes Toward Their Bearers Among Carpatho-Rusyns in Ukraine." Folklorica XXI: 1-33.

Chajęcka, Patrycja. 2015. "Narrative and economic strategies of coping with unemployment in Macedonian Poreče," Karolina Bielenin-Lenczowska,, ed. Anthropology of continuity and change: Macedonian Porece 80 years after Józef Obrębski's research. Warszawa: Instytut Slawistyki PAN, 49-69.

Chori, Iurii S. 2015a. Чорі, Юрій С. Фразеологізмы русинського языка, том 1, A-H. [Phraseologisms of the Rusyn language, vol, 1, A-N]. Ужгород: IBA. Chori, Iurii S. 2015b. Чорі, Юрій С. Фразеологізмы русинського языка, том 2, O-Я. [Phraseologisms of the Rusyn language, vol, 1, O-IA]. Ужгород: IBA. Dal', Vladimir. 1863-1866. Даль, Владимірь. Толковый словарь живаго великорускаго языка. [Explanatory Dictionary of Live Great-Russian Language] Cited by http://slovardalja.net. (consulted 13 June 2021).

Deutsche Welle. 2020. "Олігархи і ТБ: хто контролює українські телеканали? (12.06.2020)" [Oligarchs and TV: who controls Ukrainian telechannels?].

Deutsche Welle. Cited by https://www.dw.com/uk/oлігархи-і-тб-хтоконтролює-українські-телеканали-12062020/av-53788093 (consulted 20 December 2020).

Dostoevsky, Fyodor. 1862. House of the Dead. Достоевский, Федор. Записки из мертвого дома. Klassika.ru. Cited by https://klassika.ru/read.html?proza/dostoevskij/zap.txt\&page=17. (consulted 13 June 2021).

Gogol, Nikolai. 1842. Dead Souls. Гоголь, Николай. Мертвые души. Интернет Библиотека. Cited by https://ilibrary.ru/text/78/p.6/index.html. (consulted 13 June 2021).

Good, Byron J. 1994. "In the subjunctive mood: Epilepsy narratives in Turkey." Social Science \& Medicine 38(6): 835-42.

Hrinchenko, Borys. 1907-1909. Грінченко, Борис. Словарь української мови [Dictionary of the Ukrainian Language]. Кіев: Кіевская старина. Cited by http://hrinchenko.com/ (consulted 13 June 2021). 
Izquierdo, Carolina, and Allen Johnson. 2007. "Desire, Envy and Punishment: A Matsigenka Emotion Schema in Illness Narratives and Folk Stories." Culture, Medicine and Psychiatry 31(4): 419-44.

Jacobsen, Frode F. 2012. "Context and Uncertainty in Narratives: Stories of Sickness among the Beja of Northeastern Sudan." Anthropology \& Medicine 19 (3): 291-302.

Kleinman, Arthur. 2020[1988]. The Illness Narratives: Suffering, Healing, and the Human Condition. New York: Basic Books.

Nikolaev, S. L. and M. N. Tolstaia. 2001. Николаев, С.Л. и М.Н Толстая. Словарь карпатоукраинского торуньского говора, с грамматическим очерком и образиами текстов [Dictionary of Carpatho-Ukrainian dialect of Torun', with a short description of grammar and text samples]. Москва: Институт славяноведения РАН.

Onyshkevych, M. I. 1984. Онишкевич, М. Й. Словник бойківських говірок, частина перша [Dictionary of Boiko dialects, part 1]. A-Н. Київ: Наукова думка.

Paxson, Margaret. 2005. Solovyovo: The Story of Memory in a Russian Village. Washington, DC, and Bloomington, IN: Woodrow Wilson Center Press with Indiana University Press.

Phraseological dictionary of Ukrainian online. n.d. Фразеологічний словник української мови онлайн. Cited by https://slovnyk.me/dict/phraseology. (consulted 21 April 2021).

Pine, Frances. 2002. "Retreat to the household? Gendered domains in postsocialist Poland." Hann, C.M., ed. Postsocialism: Ideals, Ideologies and Practices in Eurasia. London: Routledge, 95-113.

Price, Laurie. 1987. "Ecuadorian illness stories." D. Holland and N. Quinn, eds. Cultural Models in Language and Thought. Cambridge: Cambridge University Press, 313-42.

Pyrtei, Petro.1986. Пиртей, Петро. Словник лемківської говірки [Dictionary of the Lemko dialect]. Cited by https://diasporiana.org.ua/wpcontent/uploads/books/16234/file.pdf (consulted 30 January 2021).

Rabochii Put’. 2020. “За неделю клещи "наградили" пятерых смолян болезнью Лайма" [Within a week, ticks gave Lime disease to five inhabitants of Smolensk]. Рабочии́ nуть. Cited by https://www.rabochyput.ru/news/149204-za-nedelyu-kleshchi-nagradili-pyaterykh-smolyanboleznyu-layma.html. (consulted 3 June 2021).

Ries, Nancy. 1997. Russian Talk: Culture and Conversation during Perestroika. Ithaca and London: Cornell University Press.

Sabadosh, Ivan Vasyl'ovych. 2008. Сабадош, Іван Васильович. Словник закарпатської говірки села Сокирниия Хустського району [Dictionary of a Transcarpathian dialect of the village Sokyrnytsia, Khust district]. Ужгород: Ліра. 
Slovnik ukraïns'koï movy. (1970-1980) Словник української мови. Академичний тлумачний словник [Dictionary of the Ukrainian language. Academic dictionary]. Cited by http://sum.in.ua/. (consulted 20 January 2021).

Slovnik.sk. n.d. "nadarit' sa." Cited by https://slovnik.aktuality.sk/pravopis/slovnik-sj/?q=nadarit" sa. (consulted 6 June 2021).

Tolstaia, S. M. 2019. Толстая, C.M. "Полесские похоронные причитания в сопоставлении с севернорусскими." [Funeral laments of Poles'e compared to North Russian]. S.M. Tolstaia, ed. C.M. Толстая. Славянские архаические ареалы в пространстве Европы. Мосвка: Индрик, 291329.

Tolstoi, N.I., ed. 2012. Н.И. Толстой. Славянские древности. Этнолингвистический словарь в пяти томах. Том 5: С (Сказка) - Я (Ящерица). [Slavic Antiquities: Ethnolinguistic dictionary in five volumes. Vol. 5: S (Skazka) - Ia (Iashcheritsa)]. Москва: Международные отношения.

Ukrä̈ns'ka Pravda. 2021. “Зеленський заблокував канали Медведчука: РНБО наклало санкциї” [Zelensky blocked Medvedchuk's channels: National Security and Defense Council [of Ukraine] implemented sanctions]. Украӥнська правда. Cited by https://www.pravda.com.ua/news/2021/02/2/7282097/. (consulted 23 April 2021).

Vinogradova, L. N. and E. E. Levkievskaia. 2010. Виноградова, Л. Н и Е. Е. Левкиевская. Народная демонология Полесья: Публикачии текстов в записях 80-90-х годов ХХ века. Том I: Люди со сверхъестественными свойствами [Folk demonology of Poles'e: Publication of texts collected in the 1980s - 1990s. Vol. I: People with supernatural abilities]. Москва: Языки славянских культур.

Vinogradova, L. N. and Е. E. Levkievskaia. 2012. Виноградова, Л. Е. и Е. Е. Левкиевская. Народная демонология Полесья: Публикаиии текстов в записях 80-90-х годов ХХ века. Т. ІІ: Демонологизачия умерших людей [Folk demonology of Poles'e: Publication of texts collected in the 1980s 1990s. Vol. II: Demonologization of the deceased]. Москва: Языки славянских культур.

Vorobieva, Tat'iana. 2020. Татьяна Воробьева. "В Тюмени нашли коронавирус у кошки" [In Tiumen', coronavirus was detected in a cat]. Российская Газета. Cited by https://rg.ru/2020/08/18/reg-urfo/v-tiumeninashli-koronavirus-u-koshki.html. (consulted 3 June 2021). 


\section{INTERVIEWS}

Informant A. Telephone Interview. 20 March, 13 July, 1 November 2020.

Informant B. Telephone Interview. 21 March, 11 September, 22 December 2020. Informant C. Telephone Interview. 6 April, 14 June, 18 October 2020.

Informant D. Telephone Interview. 17 October 2020, mid-March 2021, exact date unknown. 